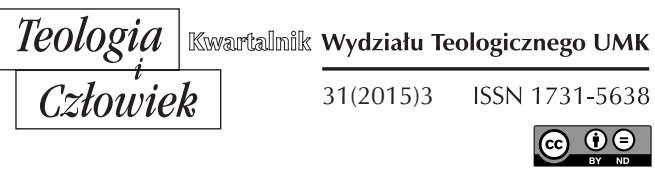

KS. GRZEGORZ WIOŃCZYK*

KATOWICE

\title{
KTO MÓWI? PYTANIE O NARRACJĘ W DOBIE PLURALIZMU
}

DOI: http://dx.doi.org/10.12775/TiCz.2015.036

Sięgając po teksty traktujące o religii lub jej konkretnych przejawach, natrafiamy na pozycje, które powstawały w różnym czasie, posiadają one różnych autorów i odnoszą się do religii w sposób właściwy dla danej dyscypliny. Nietrudno odkryć różnicę pomiędzy tekstem napisanym przez wytrawnego teologa katolickiego o swojej własnej religii, np. Istota chrześcijaństwa Brunona Fortego lub O istocie chrześcijaństwa Romano Guardiniego, a książką o tym samym tytule autorstwa Ludwiga Feuerbacha. Jednak sytuacja taka dotyczy prac zaliczanych do klasyki i autorów już w danej dziedzinie albo kraju znanej. Problem staje się jeszcze bardziej złożony, gdy zapragniemy odwołać się do kategorii czystości badań i będziemy próbować odkryć intencję autora. Powstaje w ten sposób pytanie o kryteria uprawniające do zabierania głosu w dyskusji na temat religii. Nie dotyczy to oczywiście jedynie tekstu lub tekstu naukowego.

* Ks. mgr lic. kan. Grzegorz Wiończyk, prezbiter diecezji sosnowieckiej, asystent w Katedrze Teologii Fundamentalnej, Misjologii i Filozofii Chrześcijańskiej Wydziału Teologicznego UŚ; członek Towarzystwa Teologów Dogmatyków; doktorant w Katedrze Teologii Dogmatycznej WTl UŚ; doktorant w Instytucie Filozofii UŚ. 
Doskonałą egzemplifikacją tego zagadnienia jest dylemat natury obyczajowo-prawnej, z jakim mamy do czynienia w polskim systemie oświaty. Rzadko kiedy zwraca się uwagę na doniosłą rolę refleksji metodologicznej w przypadku zatrudniania nauczycieli etyki. $Z$ jednej strony spotykamy się z lękiem, że osoba z odpowiednimi kwalifikacjami (na przykład absolwent filozofii) może nie być dobrym nauczycielem etyki, gdyż jest osobą wierzącą lub posiada również kwalifikacje do wykonywania zawodu katechety. I jednocześnie $z$ drugiej strony można spotkać się $\mathrm{z}$ zastrzeżeniami, co do moralnego aspektu nauczania etyki przez teologa. Wiąże się to niewątpliwie z postrzeganiem zajęć etyki jako konkurencyjnych względem przedmiotu „religia”, jednak nie można pomijać faktu, że zarówno osoba wierząca, jak i niewierząca nie spełniłaby dobrze swego zadania, gdyby uznała lekcje etyki za formę przekonywania uczniów do swojego światopoglądu. Jest to zatem sytuacja posiadająca wiele analogii do omawianego tu zagadnienia.

Moim celem jest podjęcie krytycznej refleksji nad narracją, jaką przyjmują autorzy tekstów traktujących o religii. Nie chodzi tu jednak o refleksję metodologiczną nad poszczególnymi naukami, ale o odpowiednie naświetlenie narracji, jaka wyłania się z konkretnego tekstu. Z tego też powodu więcej znajdzie się w tej pracy przykładów i odwołań do konkretnych pozycji niż uogólnień oraz gotowych, taksatywnych klasyfikacji. Modele narracji ponadto przecinają się z metodologiami poszczególnych dyscyplin i nie można ich w żaden sposób utożsamić.

\section{NARRACJA BEZZAłOŻENIOWA}

Byłoby świadectwem intelektualnej naiwności wierzyć, że do fenomenów kultury i religii możemy podejść bez przed-sądów. Uczciwość badań prowadzonych na gruncie filozofii i innych nauk nakazuje dogłębne zapoznanie się $\mathrm{z}$ analizowanym przedmiotem, co w pewnej mierze odsłania osobiste przeświadczenia badacza i zwiększa u niego świadomość ich istnienia. Jednak również ta procedura nie pozwala $\mathrm{z}$ nich się całkowicie uwolnić. Jak pisał Leszek Kołakowski:

[...] człowiek nie ma pozaludzkiego gruntu, na którym by stał i wiedział zarazem, że stoi. Musi zaczynać od siebie, każdy inny punkt wyjścia jest 
produktem wtórnej abstrakcji, której niepodobna uprawomocnić bez powrotu do sytuacji ludzkiej. Pytania genetyczne o człowieka zakładają fałszywie możność nadludzkiego punktu obserwacyjnego, z którego odsłania się widok na człowieka jako zrelatywizowanego. Relatywizacja człowieka $\mathrm{w}$ naukowych interpretacjach (integracja w świat przedludzki $\mathrm{w}$ teoriach ewolucji; uzależnienie percepcji od rzeczowych zachowań organizmu w fizjologicznym badaniu), czyli jego redukcja do nadczłowieczego bytu jest zawsze wtórna $\mathrm{w}$ stosunku do percepcji ${ }^{1}$.

Człowiek nie jest zdolny do uzyskania perspektywy, która pozwoliłaby mu spojrzeć na sytuację kulturową, mówiąc obrazowo, $\mathrm{z}$ innego miejsca. Jednak, jak wyjaśnia dalej Kołakowski, mit jest konieczny i trudno wyobrazić sobie jego nieobecności w kulturze ${ }^{2}$. Mit może powstać jedynie tam, gdzie pojedyncza świadomość nadaje mu powszechnie ważny sens; kiedy w pojedynczej świadomości uzyskuje on cechy gotowego wzoru pozwalającego uchwycić w pozaczasowym wymiarze całą zbiorowość, odkrywając „bezwzględnie początkową sytuację”3. W takim kontekście można powiedzieć, że mit jest świadectwem poszukiwania prawdy.

Prób odkrycia tej bezwzględnie początkowej sytuacji dokonywali wybitni myśliciele: Darwin, Husserl, Freud czy też współczesny antropolog Rene Girard. Łączyła ich wiara w możliwość objęcia całej struktury koła hermeneutycznego, które nakazuje rozumieć część w kontekście całości. Jednak, jak to zaznacza twórca hermeneutyki słabej - Gianni Vattimo całość jest nieosiągalna i jawi się raczej jako horyzont, który zmienia się wraz z położeniem interpretatora. Brak możliwości osiągnięcia oglądu całości jest właściwie tożsamy z porażką poszukiwania początku, a zatem także z niemożliwością konstruowania wypowiedzi bezzałożeniowej ${ }^{4}$.

Zofia Rosińska, badając współczesną kulturę, określiła sytuację poszukiwania początku pragnieniem powrotu. Owo łączące się ze zmęczeniem profanum pragnienie cechuje - jak to wyraża Mircea Eliade - archaiczny typ myślenia, który każe szukać wewnętrznej jedności, reprezentowanej

${ }^{1}$ L. Kołakowski, Obecność mitu, Warszawa (b.d), s. 36.

2 Por. Tamże, s. 35.

3 Por. Tamże, s. 37.

${ }^{4}$ Por. M. Januszkiewicz, Kim jestem ja, kim jesteś Ty? Etyka, tożsamość, rozumienie, Poznań 2012, s. 145. 
w kulturze przez historię powrotu Odyseusza, wędrówkę Abrahama czy też mistyczną podróż do głębi swego wnętrza, jak miało to miejsce u Teresy z Avila. Mit o początkach jest zatem wyrazem pragnienia dotarcia do rzeczy samych:

'Istnienie w micie' jest źródłem pewności, analogicznie jak źródłem pewności staje się doświadczenie oczywistości, 'duchowe unaocznienie' prawdy. I chociaż istnieje zasadnicza różnica pomiędzy mitem (tutaj: literaturą mityczną - G.W.) a Husserlową oczywistością, to i mit, i Husserlowska oczywistość stanowią wyraz pewnego 'głodu ontologicznego'. Pragnienie powrotu, ruch wsteczny, odnajdujemy również w myśli Freudowskiej ${ }^{5}$.

Prowadzenie refleksji jest zatem, jak to zauważa Paul Ricoeur, procesem budowania własnej tożsamości. Narracja zdradza mnie, pokazuje mój świat i dzięki niej ja sam staje się świadomy swojego świata „przeżywaniowego", tworzę mit, w który wierzę już uprzednio. Chodzi tutaj zatem o dowartościowanie przed-sądów w takim rozumieniu, w jakim pisał o nich Hans-Georg Gadamer6 . Mówienie jest próbą zorganizowania świata, a przez to z konieczności na świecie dokonuje się pewien gwałt, przemoc nazywania, które jest braniem w posiadanie, co widzimy już w samym obrazie Adama, który w ogrodzie rajskim nadaje imiona stworzeniom.

Nazywając, prowadząc narrację zawsze wypowiadamy się z jakiejś pozycji. Nie można mówić o trybie bezzałożeniowym, gdyż taki czyniłby z naukowca-badacza postać boską, która w jednym spojrzeniu potrafiłaby objąć wszystkie wymiary danych fenomenów religijnych i jednocześnie do każdego z nich podejść bez uprzedzeń. Zarówno chęć uzasadnienia religii, jak i jej obalenia, ukazania nieracjonalności lub zgubnych konsekwencji $\mathrm{w}$ życiu społecznym jest tak samo ugruntowana w postawach ideologicznych. Natomiast szczere poszukiwanie naukowe (nie tylko badacza konfesyjnie zaangażowanego, ale i nie zaangażowanego), które nie wiąże się $\mathrm{z}$ ideologiczną motywacją, jest zawsze zakotwiczone w przesądach grupy,

${ }_{5}$ Z. Rosińska, Pragnienie powrotu, czyli zmęczenie profanum, w: Mity współczesnej duchowości, red. Ł. Trzciński, Kraków 2010, s. 55.

${ }^{6}$ Por. J. Grondin, Wprowadzenie do hermeneutyki filozoficznej, przeł. L. Łysień, Kraków 2007, s. 144. 
kultury, z której wywodzi się badacz. Jego myślenie zaś podąża ścieżkami wyznaczonymi przez metodę, jak dobrze nas o tym poucza historia nauki. Nigdy, nie porzucając prób najlepszego oddania zastanych w świecie fenomenów religijnych, nie możemy zapominać o uwadze Nietzschego, który - negując klasyczną definicję prawdy jako adekwacji - zauważył, że nie ma faktów, są tylko interpretacje.

\section{NARRACJA TRANS-RELIGIJNA RÓŻNA OD NARRACJI BEZZAłOŻENIOWEJ}

Jeśli nie jest możliwe nieistnienie na żadnym gruncie i jednocześnie nieosiągalne jest posiadanie pełnej świadomości swych założeń badawczych, to wielu chciałoby podążyć drogą budowania refleksji pozakonfesyjnej, w której priorytetem byłaby sfera duchowa rozumiana jako taka. Ten model pragnę nazwać narracją trans-religijną. Od bezzałożeniowej różniłaby się tym, że jest świadoma swego punktu wyjścia. Model taki wydaje się być nośny szczególnie dzisiaj, w dobie uznania pluralistycznego charakteru rzeczywistości i wielości możliwych sposobów realizacji człowieczeństwa.

Ważne jest, aby precyzyjnie zdefiniować, co mamy na myśli, mówiąc o tzw. pluralizmie religijnym. Ireneusz Sławomir Ledwoń w swojej rozprawie habilitacyjnej Wyjątkowy charakter chrześcijaństwa $w$ teologii posoborowej rozróżnia pluralizm de facto od pluralizmu de iure ${ }^{7}$. Pierwszy mówi o występowaniu wielu religii w ludzkich kulturach, co stanowi fakt i jest rzeczą oczywistą. Drugi jest koncepcją teologiczną, która budowana jest z pozycji wiary, czyli nie jest li tylko deskryptywna i podlega nie tylko analizie spekulatywnej, ale także musi być odniesiona do kwestii dogmatycznych. Głosi ona, że wszystkie religie są przez Boga chciane i przez niego zamierzone, co w konsekwencji doprowadza do przyjęcia poglądu, że posiadają one wartość zbawczą. Zanim pójdziemy dalej śladem Ledwonia przyjrzyjmy się zjawiskom pokrewnym.

7 Por. I. S. Ledwoń, „... i nie ma $w$ żadnym innym zbawienia” Wyjątkowy charakter chrześcijaństwa w teologii posoborowej, Lublin 2006, s. 510. 
Anna Sobolewska w książce Mapy duchowe współczesności. Co nam zostało z Nowej Ery? atakuje Kościół Katolicki za postawę zamknięcia, w której dalej kultywuje się religijny ekskluzywizm. Ostrze jej krytyki wymierzone jest zwłaszcza w dwa dokumenty Kongregacji Nauki Wiary - Jezus Chrystus dawca wody żywej. Chrześcijańska refleksja na temat New Age oraz Dominus Iesus. O jedyności i powszechności zbawczej Jezusa Chrystusa i Kościoła. Wobec nieufności współczesnego Kościoła wspomina z nostalgią:

Kościoły zamykają bramy w sensie symbolicznym i dosłownym. Trudno dzisiaj o śmiałe inicjatywy, takie jak projekty artystyczne Janusza Boguckiego, zrealizowane w czasie stanu wojennego w kościele Miłosierdzia Bożego przy ulicy Żytniej w Warszawie w klimacie otwartości i dialogu, kultywowanym przez księdza Wojciecha Czarnockiego. Zrujnowany w czasie wojny i częściowo tylko odbudowany kościół stał się międzyreligijną przestrzenią sakralną. Do poszczególnych sal wchodziło się jak do synagogi, meczetu, sangi buddyjskiej. Nie były to tylko dekoracje. W sali buddyjskiej można było medytować na poduszkach, w innej - studiować Torę lub Koran. Wydawało się wówczas, że tak już będzie zawsze, że bramy Kościoła pozostaną szeroko otwarte dla wszystkich - dla wierzących i półwierzących, dla ateistów i panteistów ${ }^{8}$.

Jako że cała książka utrzymana jest w podobnym, może mniej biograficznym, tonie, to trudno z nią polemizować. Profesor Sobolewska sygnalizuje jednak pewien problem. Wymienione powyżej dokumenty rzeczywiście wywoływały opór nie tylko u osób, które patrzą na całą sprawę raczej intuicyjnie i emocjonalnie, ale również u teologów, którzy stoją przy katolickiej ortodoksji. Przedstawiając problem językiem spekulatywnym można powiedzieć, że jest to kwestia relatywizmu religijnego, czyli różnicy lub braku różnicy pomiędzy wieloma religiami, które istnieją (istniały) na świecie.

Linda Trinkaus Zagzebski przedstawia problem pluralizmu religijnego za pomocą metafory szczeliny ${ }^{9}$. W ten sposób określa różnicę jaka

${ }^{8}$ A. Sobolewska, Mapy duchowe wspótczesności. Co nam zostało z Nowej Ery?, Warszawa 2009, s. 31.

${ }^{9}$ L. Trinkaus Zagzebski, Wprowadzenie historyczne do filozofii religii, przeł. A. Szwed, Kraków 2012, s. 189-194. 
powstaje pomiędzy prawdą a racjonalnością. Omawiając zagadnienie ekskluzywizmu religijnego autorka proponuje oddzielić roszczenie do prawdy od roszczenia do racjonalności. Wyznawca danej religii, który stoi na stanowisku ekskluzywizmu uważa, że jego religia posiada prawdę. To zrozumiałe, ale nie wynika $\mathrm{z}$ tego jeszcze, że jako jedyna jest racjonalna. Jeśli wyznawca ten będzie w stanie powiedzieć, że choć tylko jego religia jest prawdziwa, to innym może przysługiwać/przysługuje racjonalność ich doktryny, wówczas pojawia się szczelina, która powoduje pewną nieciągłość pomiędzy niesprzecznością, racjonalnością a byciem prawdziwym. Istnieją oczywiście stanowiska, które odmawiają racjonalności innym religiom lub wykazują doniosłość swojej religii poprzez wyprowadzenie jej doktryny z przesłanek czysto filozoficznych. Przykładem tego wydają się być próby Stanisława Judyckiego ${ }^{10}$.

Właśnie owa szczelina powoduje, że Sobolewska może - nie przecząc wyjątkowemu charakterowi chrześcijaństwa - nie widzieć nic niewłaściwego w tworzeniu z kościoła „międzyreligijnej przestrzeni sakralnej”. Sytuacja nie jest zarysowana jasno, a więc pozwala na dużą dowolność decydowania. Granice pomiędzy szacunkiem a uznaniem, tolerancją a asymilacją, przy całkowitym milczeniu na temat doktryn tych religii, stają się płynne i niewyraźne. Jeśli wszystkie religie są racjonalne, to dlaczego by twierdzić, że tylko moja własna jest prawdziwa. Natomiast $\mathrm{z}$ drugiej strony nie jest możliwe, aby tylko jedna była racjonalna, w sensie niesprzeczna, gdyż o innej racjonalności w przypadku systemu wierzeń mówić chyba nie można, ponieważ nawet stosunek do rzeczywistości jest już kwestią trudną do skategoryzowania. Wynikałoby z tego, że szczelina, o której mowa nie tyle pozwala na budowanie „międzyreligijnej przestrzeni sakralnej”, co ustanawia pewien metapoziom religijny, w którym wierzący nie tyle się spotykają (w sensie dialogicznym), co zbierają się, aby podejmować różne działania religijne obok siebie, gdyż nie ma już znaczenia, co kto uważa za słuszne.

Ten jawny relatywizm religijny może przybrać formę bardziej subtelną. Znamy ją z propozycji Johna Hicka. Mariusz Wojewoda, komentując jego hipotezę pluralizmu religijnego, wyjaśnia, że odwołuje się ona do Paula Tillicha, jego rozumienia wiary religijnej jako troski o to, co dla

10 S. Judycki, Bóg i inne osoby. Próba z zakresu teologii filozoficznej, Poznań 2010. 
człowieka ma fundamentalne znaczenie oraz do kantowskiego rozróżnienia świata zjawisk i rzeczy samych w sobie ${ }^{11}$. „Hick uznał, że objawienie podstawowe dokonało się w Rzeczywistości Ostatecznej, w wymiarze noumenalnym, natomiast wyznawcy różnych religii poznają je w postaci wielu objawień fenomenalnych"12 - twierdzi filozof.

Propozycja Hicka posiada wiele braków i nie rozwiązuje problemu. Przede wszystkim należy zauważyć, że dla Kanta świat fenomenów jest jeden oraz opiera się na kategoriach wspólnych dla wszystkich ludzi, koniecznych, jest aprioryczny, kiedy światy fenomenów religijnych Hicka są wyprowadzane empirycznie.

Wspomniany już wcześniej francuski antropolog - Rene Girard nie przystałby na żadną z powyższych propozycji, gdyż uważa, że istnieją różnice pomiędzy religiami, a najważniejszą z nich jest ich stosunek do mechanizmu generowania ofiar. $Z$ tej perspektywy docenia wartość tych religii, które są bliskie chrześcijańskiemu uwalnianiu ofiary od jej domniemanej winy. Jak zauważa, religie wschodnie często jawią się jako pokojowe, ale nie są całkowicie wolne od elementu ofiarniczego i nie mają siły przemieniania świata, którą ma chrześcijaństwo. Inne zaś swój rys odchodzenia od ofiary zawdzięczają właśnie chrześcijaństwu, gdyż od niego go przejęly ${ }^{13}$.

Rozumowanie takie jest oparte na tezie, że o wartości religii świadczy jej udział w prawdzie Objawienia. Girarda nie interesuje kwestia Rzeczywistości Ostatecznej Hicka, nie podejmuje tego ani podobnych tematów. Nawet gdyby przyjąć owo twierdzenie za słuszną hipotezę pluralizmu religijnego, to na gruncie teorii mimetyczno-ofiarniczej ważniejsze jest to czy ów udział w objawiającej sile religii został zauważony $\mathrm{w}$ świecie fenomenalnym. To spostrzeżenie ukazuje jasno, że mamy tutaj do czynienia $z$ narracją antropologiczną, a nie teologiczną, chociaż Girard w sposób jawny opowiada się za chrześcijaństwem. Wszystko rozbija się jednak o koncepcję Objawienia, jaką przyjmuje autor Kozła ofiarnego.

${ }^{11}$ Por. M. Wojewoda, Pluralizm aksjologiczny i jego implikacje we współczesnej filozofii religii, Katowice 2010, s. 239-264.

12 Tamże, s. 240.

13 Por. R. Girard, Początki kultury, przeł. M. Romanek, Kraków 2006, s. 122-125. 
Objawienie jest dla niego procesem niesienia informacji, zatem jest obecna nie tyle w rzeczywistości, co w tekście wiadomość o ofierze, którą nienawidzono bez powodu. Jak już było powiedziane, Objawienie w takim rozumieniu, jakie przyjmuje Girard mogłoby istnieć równie dobrze poza instytucjonalnym Kościołem ${ }^{14}$, to prawda tekstu decyduje o jego rewelatorskiej sile. Wybrzmiewa ona najgłośniej w Ewangelii, gdyż ta ukazuje niewinność ofiary - Jezusa, w przeciwieństwie do mitologicznego oskarżenia i skazania (np. król Edyp).

Wracając do propozycji Ledwonia, należy zwrócić uwagę na fakt, że teologowi powinno być bliższe stanowisko autora Kozła ofiarnego, ponieważ ten wykazuje różnicę pomiędzy religiami archaicznymi i religiami wschodnimi a chrześcijaństwem. Trzeba jednak pamiętać o problemie szczeliny pomiędzy racjonalnością oraz prawdziwością. Jak już zasugerowano, rozwiązanie leży w rozumieniu Objawienia. W różnych religiach, nie tylko w chrześcijaństwie, Objawienie nie jest rozumiane jedynie jako odsłonięcie (łac. revelatio) jakiejś prawdy o świecie, istoty absolutnej, ale bardzo często, a w chrześcijaństwie i judaizmie z całą wyrazistością, chodzi w Objawieniu o przymierze, jakie jest związane z tym odsłonięciem. Ujawnienie imienia Boga w Torze jako tego, który składa obietnicę swojej obecności (Będę, który będę) mówi o trwałej relacji Boga i człowieka. Jezus mówi o wewnętrznym nawróceniu, ale nawrócenie to nie dokonuje się mocą samego odkrycia i unieważnienia mechanizmu ofiarniczego, ale trwania w przyjaźni z Nim, jak o tym świadczy wysoko przez Girarda ceniony tekst Ewangelii Jana, zwłaszcza rozdział 17.

Należy także pamiętać, że Objawienie jest procesem, co trzeba rozumieć analogicznie do tego, jak Girard twierdził o religii (interpretacja figuratywna). Jeśli uznamy, że genezą innych religii jest jakiś typ Objawienia, to, nawet przy niskim poziomie rozumienia roli ofiary, odnajdziemy $\mathrm{w}$ nich elementy teandrycznego przymierza. Można teraz zadać pytanie o to, czy jest to rozwiązanie jedynie teologiczne. Na pewno w całej swej rozciągłości może być uznane jedynie przez katolickiego/chrześcijańskiego teologa, ale trzeba zauważyć, że jest ono filozoficznie atrakcyjne, a ponadto nie wpisuje się w krytykowaną przez Sobolewską scenerię

${ }_{14}$ Por. Tenże, Dawna droga, którą kroczyli ludzie niegodziwi, przeł. M. Goszczyńska, Warszawa 1992, s. 10. 
lęku. Trudno je wkomponować na stałe w założenia filozofii religii, gdyż powstało niewątpliwie $\mathrm{w}$ obrębie myślenia religijnego. Jednak sama idea Objawienia jako przymierza może być włączona w teorię filozoficzną, gdyż jest elementem zastanym w religii jako takiej. Powinna ją uznać także etnologia, jeśli nie chce ograniczyć się jedynie do ujęcia pozytywistycznego. Podsumowując, zwróćmy uwagę na to, co komunikuje nam Ledwoń w swojej rozprawie opracowanej na gruncie teologii chrześcijańskiej:

Religie ludzkości i ich zróżnicowanie są więc wyrazem bogactw rozdzielonych pomiędzy ludzi i ludzkie społeczności przez Boga; żeby użyć (...) wyrażenia Mikołaja z Kuzy - pozwalają tym samym lepiej jaśnieć Bożej chwale. Każda religia reprezentuje określoną ludzką odpowiedź wiary na Boże objawienie, udzieloną wewnątrz danej kultury, przy pomocy konkretnego języka itd., i zgodnie z możliwościami danego człowieka i danej społeczności ${ }^{15}$.

Tym, co odróżnia koncepcję Ledwonia od hipotezy Hicka jest fakt, że unika zarzutu relatywizmu, gdyż:

uznaje bezwzględną nadrzędność chrześcijaństwa i jedyność zbawczego dzieła Jezusa Chrystusa, w związku z czym każde zbawienie dokonujące się poza widzialnymi granicami chrześcijaństwa i Kościoła postrzega jako łaskę pochodzącą od Jezusa Chrystusa, udzieloną przez Ducha Świętego za pośrednictwem Kościoła ${ }^{16}$.

Jeśli za Jacquesem Derridą przyjąć, że istnieje tylko tekst, to nie wolno negować ani rozwiązania Girarda, w którym religie archaiczne poddane są ostrej krytyce i jawią się jako niebezpieczeństwo, ani teologicznej koncepcji pluralizmu de iure, ani relatywizmu religijnego. Czy jednak rzeczywiście koncepcje te są zawsze tak samo prawdziwe? To pytanie dotyczy problemu szerszego niż tu omawiany, ale możemy mieć słuszne obiekcje, co do takiego rozwiązania. Tekst będący świadectwem Objawienia postawiony w centrum narracji danego rodzaju myślenia systematycznego zawsze będzie służył za narzędzie interpretacyjne dla innych tekstów. Girard wybiera Ewangelię nie z powodów konfesyjnych,

15 I. S. Ledwoń, dz. cyt., s. 511.

16 Tamże. 
ale wynikających $\mathrm{z}$ antropologicznego dochodzenia. Jeśli Ewangelia jest kryterium oceny religii (pluralis), to trudno z kolei zgodzić się z oceną religii niechrześcijańskich, jaką wysuwa Girard, gdyż bazuje ona na zawężonym rozumieniu Objawienia. Opierając się na samych tekstach biblijnych, można potwierdzić racjonalność wniosków Ledwonia, co z kolei oznacza, że do poszanowania innych religii nie jest konieczne tworzenie narracji trans-religijnej. Ta z kolei jest jedynie ukrytym relatywizmem.

\section{NARRACJA WOBEC MOTYWACJI MÓWIĄCEGO}

Ojcowie dominikanie są organizatorami Wykładów otwartych $z$ teologii naturalnej im. O. Bocheńskiego. Już samo pojęcie teologii naturalnej wydaje się być wielce obiecujące w kwestii narracji. Kim jest człowiek uprawiający teologię naturalną? Nawiązując do tytułu możemy zapytać: Kto mówi?

Wykłady u dominikanów rozpoczął prof. Stanisław Judycki. Na kanwie tego spotkania powstały dwie książki - Bóg i inne osoby. Próba z zakresu teologii filozoficznej oraz zbiór tekstów będących zapisem debaty wokół tej książki. Właśnie w tej drugiej pozycji natrafiamy na ciekawą refleksję Ireneusza Ziemińskiego. Autor, zadając sobie pytanie o możliwe sposoby odczytania tekstu książki Judyckiego, mówi, że mogą być one dwa. W pierwszym przypadku, zgodnym z deklaracją Judyckiego, teologia filozoficzna to namysł filozoficzny nad religią chrześcijańską i - co ważne dodaje dalej, że jest to namysł dokonany $\mathrm{z}$ wnętrza wiary ${ }^{17}$.

To ostatnie stwierdzenie jest bardzo istotne, bowiem w taki sposób definiuje się sama teologia chrześcijańska. Jest to mówienie z wnętrza wiary, ze środka teologii, z głębi doświadczenia Boga.

Jeśli zatem mówimy, że osoba uprawiająca teologię filozoficzną dokonuje namysłu $\mathrm{z}$ wnętrza wiary, to przynajmniej funkcjonalnie zbliżamy do siebie teologię i filozofię. Jest to zatem narracja teologiczna w najgłębszym sensie tego słowa, chociaż nie przyjmuje ona faktu Objawienia jako punktu wyjścia. Narracja filozoficzna jest dzięki temu narracją teologiczną,

17 Por. I. Ziemiński, Summa filozofii chrześcijańskiej, w: Teologia filozoficzna. Wokół książki Stanisława Judyckiego „Bóg i inne osoby”, red. J. Pyda, Poznań-Kraków 2013, s. 503-504. 
ale nie w znaczeniu ortodoksyjności lub metodologii, ale motywacji, do czego jeszcze powrócimy.

Ziemiński zauważa:

Ten sposób uprawiania teologii filozoficznej należy uznać za prawomocny, skoro bowiem nie ma filozofii bezzałożeniowej ani światopoglądowo neutralnej, zwolennik teizmu ma prawo korzystać ze swej wiary, a nawet doświadczeń religijnych. Podobnie zresztą postępuje filozof ateista, który, mając nieodparte doświadczenie nieobecności (a nawet niemożliwości) Boga, konstruuje argumenty uzasadniające słuszność swego stanowiska ${ }^{18}$.

Są to słowa o tyle ważne, że po pierwsze - potwierdzają to, co już zostało powiedziane, a po drugie - system Judyckiego jest racjonalistyczny i bazuje na rozwiązaniach Anzelma.

Co do drugiego sposobu odczytania treści książki, Ziemiński zauważa, że można ją rozumieć jako próbę zbudowania systemu metafizyki teistycznej opartego wyłącznie na racjach rozumu ${ }^{19}$. W ten sposób recenzent wskazuje nam właściwy problem w rozważaniach na temat narracji. Chociaż tekst naukowy musi posiadać właściwą strukturę i być skomponowany za pomocą odpowiedniej dla danej nauki aparatury pojęciowej i metodologicznej lub też proponować nową, która z powodzeniem mogłaby zastąpić zastaną, to nie oznacza to, że tekst taki jest jednoznaczny. Odwołując się do eksperymentu Stanleya Fisha, który grupie studentów literaturoznawstwa przedstawił katalog nazwisk językoznawców, twierdząc, że jest on wierszem, czego rezultatem było uzyskanie interpretacji katalogu jako poezji, możemy potwierdzić, że interpretacja nie jest odczytaniem tekstu, ale jego tworzeniem ${ }^{20}$. Oczywiście nie oznacza to dowolności interpretacji, ale jednak nigdy nie można zapomnieć, że interpretacja właściwa i pełna nie jest w zasięgu naszej możliwości, podobnie jak nie jest dostępna całość w konstrukcji koła hermeneutycznego. Trzeba się zgodzić z Ryszardem Nyczem, który pisze że:

18 Tamże.

19 Tamże, s. 504.

20 Zob. S. Fish, Interpretacja, retoryka, polityka, przeł. A. Grzeliński, Kraków 2007, s. 81-85. 
nie potrafimy wyraźnie oddzielić cech sposobu poznania (języka opisu) od cech przedmiotu (rezultatu); nie umiemy ostatecznie rozstrzygnąć, czy to, co opisujemy, jest odkrywane w tekstach, czy też jest efektem zastosowanych konwencji analitycznych ${ }^{21}$.

Uwagę Nycza możemy zastosować tak do samego problemu mówienia o religii, czyli przekładania rzeczywistości na język opisu, jak i do samego odczytania tekstów dotyczących religii.

Jeśli ten sam tekst możemy rozumieć jako apologię chrześcijaństwa albo jako próbę tworzenia metafizyki opartej o dowód na istnienie istoty najwyższej, oznacza to, że wskazanie typu narracji jest wydane naszej interpretacji, która musi pozostawać wierna tekstowi, ale również powinna, z konieczności, odbywać się w powiązaniu z każdorazowym czytelniczym „ja”. Nie sposób zatem odkryć właściwej motywacji Judyckiego, Girarda i innych myślicieli zajmujących się nieteologicznym dyskursem o Bogu w jego chrześcijańskim ujęciu. Większość czytelników zaufałaby z pewnością deklaracji piszącego, chociaż przy współczesnych problemach $\mathrm{z}$ autorem nie można interpretacji autorskiej uznać za jedyną, gdyż poza możliwością jej zdekonstruowania za pomocą technik podsuniętych nam przez mistrzów podejrzeń, można również podnieść kwestię niereferencyjności tekstu, na co wskazał Jacques Derrida. Interpretacja autora jest jedynie kolejnym tekstem, który trzeba postawić obok tekstu właściwego.

Dla porządku jednak warto zastanowić się nad ujawnionymi motywacjami książki Judyckiego. W polemice z Mateuszem Przanowskim autor wskazał na antymodalistyczną motywację swoich rozważań ${ }^{22}$. Celem filozoficznej trynitologii Judyckiego jest zatem obrona odrębności osób w Trójcy Świętej, która nie pozwala rozumieć ich jako poszczególnych sposobów objawiania się, działania i istnienia Boga. Oznacza to, że chociaż tekst pozostaje tekstem filozoficznym, to przyjmuje na siebie funkcję apologetyczną sensu stricto. Filozoficzność polega na użyciu odpowiedniej metody, tutaj zgodnej ze szkołą analityczną, oraz zastosowaniu kombi-

${ }^{21}$ R. Nycz, Kulturowa natura, staby profesjonalizm. Kilka uwag o przedmiocie poznania literackiego i statusie dyskursu literaturoznawczego, w: Kulturowa teoria literatury. Główne pojęcia i problemy, red. M. P. Markowski, R. Nycz, wyd. 2, Kraków 2012, s. 21.

${ }^{22}$ S. Judycki, Odpowiedź drowi Mateuszowi Przanowskiemu, w: Teologia filozoficzna. Wokół książki Stanisława Judyckiego „Bóg i inne osoby”, s. 451. 
natoryki myślowej, jak to ujmuje Jacek Wojtysiak w swojej książce Spór o istnienie Boga. Analityczno-intuicyjny argument na rzecz teizmu, opartej wyłącznie na racjonalnych przesłankach. Narracja taka nie może być zatem uznana za ideologiczną. Nie dochodzi w niej do nadużyć i zniekształceń rzeczywistości, chociaż w mocy pozostaje uwaga Ziemińskiego, który podkreśla, że próby Judyckiego są natury eksluzywistycznej i dowodzą prawdziwości jednej religii, co nakazuje konfrontowanie wyników badań z podobnymi próbami racjonalizacji judaizmu lub islamu. Jest to doskonały przykład niepokrywania się ze sobą narracji właściwej dla danej dyscypliny nauki z narracją właściwą dla konkretnego tekstu. Jeszcze lepiej wyjaśnia tę kwestię fragment książki Bóg i inne osoby, w którym czytamy, że odwołania do Objawienia należy rozumieć nie w kontekście uzasadnienia, ale w kontekście odkrycia ${ }^{23}$.

Judycki w dyskusji z Januszem Pydą podaje jeszcze jedno wyjaśnienie, które wcześniejszy podział nieco rozmywa i wskazuje drogę być może pośrednią lub też złożoną z dwóch wskazanych przez Ziemińskiego strategii czytania równolegle. Pisze:

Patrząc od strony czysto emocjonalnej, zawsze miałem na celu jakiś rodzaj obrony wszystkich istnień ludzkich, jakie się dotąd pojawiły i jakie się pojawią. Nic innego nie wydawało mi się ważniejsze niż ta kwestia ${ }^{24}$.

Biorąc pod uwagę tę deklarację, trzeba przyznać, że chociaż dzieło ma wymiar apologetyczny, to jednak obrona wiary w Trójcę Świętą (odrębność osób) jest jedynie zagadnieniem, jakie należy rozważać na tle swoistego personalizmu myślenia Stanisława Judyckiego. Rys ten jest widoczny, a przez to niejako potwierdzony, już w tytule książki. Należałoby zatem skorygować tezę o dokonanej próbie utworzenia teistycznej i trynitarnej metafizyki oraz zaznaczyć, że próba ta ma wymiar właściwy dla filozofii osoby.

23 Por. S. Judycki, Bóg i inne osoby. Próba z zakresu teologii filozoficznej, s. 11.

${ }^{24}$ Tenże, Odpowiedź mgrowi Januszowi Pydzie OP, w: Teologia filozoficzna. Wokót książki Stanisława Judyckiego „Bóg i inne osoby”, s. 483. 
Narracja jako snucie opowieści jest niejawną stroną tekstu. Dochodzimy do niej poprzez interpretację. Czytając, konfrontując się z opowieścią zawartą w tekście, przyjmujemy, choćby dla lepszego zrozumienia, pozycję opowiadającego, który jest interpretatorem rzeczywistości lub jej twórcą. Kiedy opowieść ta podejmuje wątki związane z religią lub religiami, sposób jej przedstawienia jest bardzo istotny ze względu na dużą ulotność materiału, jego ogromny ładunek duchowy i wpisanie w kulturowy kontekst. W badaniu narracji nie chodzi o autorski zamysł, ale o odkrycie sposobu, a także celu użycia faktów, które nigdy nie są nagie, jak to zostało podkreślone $\mathrm{w}$ punkcie omawiającym narrację bezzałożeniową. Nie chodzi także o zrozumienie autora w sposób doskonalszy niż on sam rozumiał siebie, na co wskazywała jeszcze hermeneutyka nowożytna. Zawiłości takiej analizy i jej ostateczna niekonkluzywność została zaprezentowana na przykładzie książki Stanisława Judyckiego. Chodzi natomiast z całą pewnością - chociaż nie tylko - o swego rodzaju krytyczną lekturę, która ukazuje, że to, co deklarowane jako neutralne może okazać się opowiadane z punktu widzenia konkretnego, jak również możliwego do określenia stanowiska. Głównie taki cel miała część poświęcona narracji trans-religijnej. W tym kontekście należy zauważyć, że narracja przyjmowana przez teologa dogmatyka jest takim sposobem mówienia, który ujawnia swoje konfesyjne zaangażowanie i czyni przez to tekst pod tym względem klarownym, co świadczy o jego hermeneutycznej transparentności.

Narracje spotykają się ze sobą w taki sam sposób, w jaki spotykają się ludzie. Każdorazowa konfrontacja z tekstem jest konfrontacją z Innym, w levinasowskim znaczeniu tego zwrotu. Inny wtargnął w mój świat w momencie lektury i, przedstawiając swoją opowieść, chce, abym nawet ja opowiadał o swoim doświadczeniu w sposób zaproponowany przez niego. Podobnie jak pluralizm religijny zmusza nas do ciągłego redefiniowania naszych oraz omawianych przez nas struktur religijnych, tak też pluralizm w sposobach realizacji naszego człowieczeństwa wymusza na nas szacunek dla opowieści Innego. Szacunek ten nie może oznaczać bezrefleksyjnej afirmacji, wymieniania tego, co moje, na to, co przybyłe spoza mnie, chociaż i tutaj trzeba mieć w pamięci normę hermeneutyczną, 
na jaką wskazał Hans-Georg Gadamer, kiedy mówił: „Inny może mieć rację" 25 .

W opowieści kryje się tło, które jest tłem opowiadającego. Bartosz Brożek w książce Granice interpretacji zwrócił uwagę na fakt zależności interpretacji od modelu świata. Ta kwestia stanowi częsty element myślenia hermeneutycznego, jednak Brożek odwołał się do zagadnienia Modelu/ modelu także w znaczeniu wiedzy przyrodniczej i koherentnej wizji świata interpretatora ${ }^{26}$. Osoba wierząca, która podejmuje wypływającą z wiary refleksję nad tą wiarą, prowadzi swe badania, a zatem buduje proces rozumienia, w oparciu o pewien model świata, który stanowi dla niej scenę historii zbawienia. W tym znaczeniu można powiedzieć, że jej refleksja obejmuje wszystkie aspekty jej świata przeżywaniowego (Lebenswelt), jednak bez popadania w myślenie systemowe $\mathrm{w}$ rozumieniu Nicolaia Hartmanna. Model ten może być zastąpiony innym, jednak zawsze będzie obecny jako tło mowy mówiącego.

Nigdy jednak nie można zapominać, że proces rozumienia, w który wpisuje się określanie narracji, jest wystawiony na niebezpieczeństwo nieporozumienia. Hermes to tłumacz woli bogów, ale to także krętacz i opiekun złodziei, zatem stale należy pamiętać, że nie tylko opisując religie, stoję na gruncie, którego nie potrafię ująć, ale również konfrontując się z inną narracją, sam przystępuję do interpretacji wraz z własnymi przed-sądami.

Streszczenie. Religia jest fenomenem, jaki może być badany w ramach różnych paradygmatów naukowych w obrębie różnych dyscyplin. Zwrot hermeneutyczny, a także zwrot lingwistyczny uświadomiły nam, że nie jest możliwe zdystansowanie się od przedmiotu badania, co oznacza, że teolog konfesyjnie zaangażowany w tej materii nie różni się od badacza religii, który nie przystępuje do niego z powodów religijnych. Próba budowania refleksji trans-religijnej w konsekwencji jawi się także jako swego typu narracja zaangażowana, w tym przypadku na rzecz relatywizmu religijnego. Odwołując się natomiast do kategorii motywacji piszącego, trzeba przyznać, że może ona w sposób prawomocny i niedyskredytujący wykazywać cechy konfesyjne i nie sprawia, że tekst z tej motywacji powstały przestaje być tekstem naukowym. Narracja przyjmowana przez teologię dogmatyczną jest zatem takim sposobem mówienia, który ujawnia swoje konfe-

${ }^{25}$ Por. J. Grondin, Hans-Georg Gadamer. Biografia, przeł. J. Wilk, Wrocław 2007, s. 334.

${ }^{26}$ Zob. B. Brożek, Granice interpretacji, Kraków 2014, s. 202-210. 
syjne zaangażowanie oraz czyni tekst pod tym względem klarownym, co świadczy o jej hermeneutycznej transparentności.

Słowa kluczowe: narracja; pluralizm religijny; interpretacja; metodologia teologii.

Abstract. Who is speaking? The Question about Narration in the Age of Pluralism. Religion is a phenomenon, which can be examined in various scientific paradigms, within different disciplines. The hermeneutic turn and the linguistic turn have made us aware that it is not possible to distance oneself from the subject of the research, which means that a theologian, engaged in this matter in religious terms, is not different from a religion researcher who does not commence conducting such research for religious reasons. As a result, the attempt to construct trans-religious reflection is also presented as a kind of a narration, involved, in this case, in religious relativism. However, referring to the category of motivation of the author, it must be admitted that in a valid and not discrediting manner it can have religious features and it does not result in the fact that a text written from such a motivation ceases to be a scientific text. A narration assumed by dogmatic theology is, therefore, such a manner of speaking which reveals its religious involvement and makes the text clear in this respect, which proves its hermeneutic transparency.

Keywords: narration; religious pluralism; interpretation; theology methodology. 
